Nastavnička revija 2 (2021) 1, 76-87

https://doi.org/10.52444/nr.2.1.5

Primljeno: 24. ožujka 2021.

Prihvaćeno: 3. lipnja 2021.

Stručni članak

\title{
PALIJATIVNA SKRB U PEDIJATRIJI
}

\author{
Monika LOVREK SENIČIĆ, mag. med. techn. \\ Škola za medicinske sestre Vinogradska \\ Vinogradska cesta 29, 10000 Zagreb \\ dlovrek@gmail.com
}

\author{
Miroslava KIČIĆ, mag. med. techn. \\ Medicinski fakultet Osijek \\ Josipa Huttlera 4, 31000 Osijek \\ mkicic81@gmail.com
}

\begin{abstract}
Alma KARABEGOVIĆ, mag. med. techn.
Škola za medicinske sestre Vinogradska Vinogradska cesta 29, 10000 Zagreb

karabegovic.alma@gmail.com
\end{abstract}

\section{SAŽETAK}

Palijativna skrb djece definirana je i određene su jasne smjernice o njenoj organizaciji, no zbog svoje specifičnosti i kompleksnosti još uvijek je nedovoljno razvijena. U formalnoj edukaciju medicinskih sestara na preddiplomskim i diplomskim studijima su uvedeni i zasebni kolegiji koji obrađuju teme palijativne zdravstvene njege. Iako je svaki dio palijativne skrbi važan sam po sebi, naglasak bi trebalo staviti na prepoznavanje i liječenje boli te dobru komunikaciju s roditeljima. Važnu ulogu u palijativnoj skrbi za djecu imaju volonteri. Edukacija volontera u dječjoj palijativnoj skrbi zahtjeva dodatnu dimenziju, koja uključuje specifičnu edukaciju iz dječje palijativne skrbi. Kako palijativna skrb djece počinje s trenutkom dobivanja dijagnoze koja zahtjeva palijativnu skrb i traje kroz proces žalovanja obitelji nakon smrti djeteta, izazov je zadržati empatiju.

Ključne riječi: djeca, palijativna skrb, roditelji. 
M. Lovrek Seničić, M. Kičić, A. Karabegović, Palijativna skrb u pedijatriji

\section{UVOD}

Suvremena medicina osim preventivne i kurativne uključuje i palijativnu medicinu. U promicanju palijativne medicine i palijativne skrbi istaknula se liječnica Cicely Saunders iz Velike Britanije, a standarde palijativne skrbi u pedijatriji postavila je skupina zdravstvenih djelatnika iz Europe, SAD-a, Kanade i Libanona na sastanku u Trentu, Italija, 2006. godine. Godinu dana kasnije ta skupina zdravstvenih djelatnika u sklopu Europske udruge za palijativnu skrb napravila je dokument o palijativnoj skrbi u pedijatriji. Svjetska zdravstvena organizacija definira palijativnu skrb kao pristup koji poboljšava kvalitetu života bolesnika i njihovih obitelji suočenih $\mathrm{s}$ problemima povezanima sa smrtonosnom bolešću, primjenom prevencije i olakšanja patnje. To se postiže ranim prepoznavanjem bolesti te besprijekornom procjenom i suzbijanjem boli i drugih fizičkih, psihosocijalnih i duhovnih potreba. Definicija palijativne skrbi kod djece Svjetske zdravstvene organizacije kaže da je to aktivna i potpuna skrb o djetetovom tijelu, njegovom umu i duhu te uključuje podršku obitelji (World Health Organization). 7.listopada 2016. godine donesena je Zagrebačka deklaracija o dječjoj palijativnoj skrbi na 2. simpoziju o pedijatrijskoj palijativnoj skrbi. $\mathrm{Na}$ simpoziju su sudjelovali Hrvatski liječnički zbor, Sekcija za pedijatrijsku palijativnu skrb Hrvatskog društva za palijativnu medicinu i Hrvatsko pedijatrijsko društvo. Deklaracija se sastoji od definicije palijativne skrbi, nabrojana su stanja koja podrazumijevaju pedijatrijsku palijativnu skrb, spomenuti su IMPaCCT standardi te je navedeno što sve treba osigurati kako bi se razvila pedijatrijska palijativna skrb. Naglasak je stavljen na suradnju $s$ Ministarstvima zdravlja te socijalne politike i mladih, ali i nekih institucija kao što je crkva. Zatim je spomenuta važnost kako se palijativna dječja skrb treba uključiti u svaku dječju zdravstvenu ustanovu te važnost zakonskog definiranja i edukacije volontera za $\operatorname{rad} \mathrm{u}$ dječjoj palijativnoj skrbi ( Zagrebačka deklaracija o dječjoj palijativnoj skrbi, 2016). U Hrvatskoj djeluje Centar za palijativnu medicinu, medicinsku etiku i komunikacijske vještine Medicinskog fakulteta Sveučilišta u Zagrebu (CEPAMET) koji kontinuirano provodi edukaciju različitih profila profesionalaca koji rade $\mathrm{s}$ bolesnicima $\mathrm{s}$ teškim $\mathrm{i}$ neizlječivim bolestima (Centar za palijativnu medicinu, medicinsku etiku i komunikacijske vještine, 2010.). Kada je riječ o temeljnoj naobrazbi medicinskih 
sestara, kurikul medicinske sestre opće njege/medicinski tehničar opće njege nema u svome sadržaju nastavni predmet koji podrazumijeva palijativnu skrb. Medicinski fakultet u Puli kao dio cjeloživotnog obrazovanja nudi dva modula Palijativna skrb s kliničkom praksom, za jedan je uvjet završena srednja medicinska škola, dok je drugi namijenjen nezdravstvenom osoblju (Medicinski fakultet u Puli, Cjeloživotno obrazovanje, Palijativna skrb s kliničkom praksom). Zdravstveno veleučilište $u$ Zagrebu na preddiplomskom studiju sestrinstva od 2001. godine kao izborni, a od nedavno i kao obavezan kolegij ima Palijativnu zdravstvenu njegu. Hrvatsko katoličko sveučilište u svom planu i programu kroz obavezne i izborne predmete ima kolegije palijativne skrbi i na preddiplomskom i na diplomskom studiju sestrinstva (Hrvatsko katoličko sveučilište, Izvedbeni planovi - sveučilišni studij sestrinstva). Radna skupina za usklađivanje studijskih programa sestrinstva s odredbama Direktive 2005/36/EC izradila je zajednički obvezni dio studijskog programa sestrinstva, takozvani core curriculum s kojim su sva visoka učilišta uskladila svoje preddiplomske studije a prema kojem se na trećoj godini preddiplomskog studija sestrinstva nalazi kolegij Palijativna zdravstvena njega (Odluka o zajedničkom obaveznom dijelu preddiplomskog sveučilišnog i preddiplomskog stručnog studijskog programa sestrinstva, 2011).

\section{PALIJATIVNA SKRB KOD DJECE}

Palijativna skrb kod djece započinje onog trenutka kada je postavljena dijagnoza, bez obzira dobiva li dijete neki oblik terapije ili liječenja za tu bolest koja mu je dijagnosticirana. Štoviše, palijativna skrb djetetu se pruža usporedno $\mathrm{s}$ aktivnim liječenjem kojem je svrha izlječenje bolesti te se nastavlja kao podrška tijekom procesa žalovanja nakon smrti djeteta. Palijativna skrb djece podrazumijeva ublažavanje svih simptoma i potreba, prije svega ublažavanje boli. S obzirom na kronično trajanje boli, organizam se prilagođava no dijete mijenja svoje ponašanje, postaje mirno, ne može se koncentrirati pa djeluje nezainteresirano, ima nesanice i odbija hranu (Filipušić; Horvat; Lovrek Seničić, 2020). Istraživanje koje je provela radna grupa za maligne bolesti u Velikoj Britaniji na uzorku od 185 maligno oboljele djece zaključuje kako je broj simptoma znatno veći na kraju nego na početku palijativne skrbi pa to upućuje na činjenicu da je, kako bolest napreduje, sve teže kontrolirati simptome (Šilje, 2016). Djeca mlađa od 3 godine ne mogu 
verbalizirati svoju bol i uglavnom ovise o tome hoće li osobe koje ih njeguju prepoznati fiziološke parametre boli kao što su tahikardija i tahipneja, hipertenzija, znojenje, plač i grimase kojima pokazuju bol (Butković, 2014) . Emocionalne boli često su veće od tjelesnih do te mjere da povećavaju tjelesnu bol (Vuletić i dr., 2014). Pri procjeni boli $\mathrm{u}$ obzir treba uzeti kognitivni razvoj djeteta te oštećenje neurološkog sustava ili nemogućnost verbalizacije boli pa se umjesto uobičajenih VAS ljestvica za fiziološke pokazatelje koristi FLACC ljestvica kod procjene boli. Bol od koje djeca najviše strahuju je proceduralna bol koja se javlja kao posljedica mnogih zahvata kojima je dijete izloženo (Bedeković Sliško, 2018). Kao i kod svih, tako i kod djece, palijativnu skrb obavlja multidisciplinarni tim raznih profesija, od zdravstvenih djelatnika i obitelji, duhovnika, fizioterapeuta, nutricionista, socijalnog radnika, psihologa koji pomažu ne samo djetetu već i roditeljima. Njihov pristup djetetu uvijek mora biti holistički. Osim toga, članovi tima moraju poznavati tijek bolesti od koje dijete koje zahtjeva palijativnu skrb boluje jer će drukčiji tijek imati dijete koje, na primjer, boluje od onkološke bolesti, a drukčiji tijek dijete koje boluje od cistične fibroze.
Palijativna skrb djeteta tako za cilj ima poboljšati kvalitetu života i djeteta kojem se skrb pruža i njegovoj obitelji te zadovoljava fizičke, psihološke, emocionalne, duhovne i socijalne potrebe bez obzira nalazi li se dijete u nekoj ustanovi ili u svome domu. Roditeljima treba pružiti podršku u odluci da se palijativna skrb za dijete nastavi $u$ obiteljskom domu kada god je to moguće.

\subsection{Palijativna kućna skrb za djecu}

Palijativna kućna skrb obuhvaća mobilni palijativni tim koji se sastoji od liječnika i medicinske sestre koji po pozivu liječnika ili medicinske sestre iz primarne zdravstvene zaštite ili ustanove iz koje se otpušta dijete na kućnu palijativnu skrb posjećuju obitelj i pružaju specijalističku palijativnu skrb u domu. Organizacijski oblici palijativne skrbi za djecu osim spomenute palijativne skrbi kod kuće su dnevne bolnice za palijativnu skrb i pedijatrijske palijativne postelje (Ministarstvo zdravstva, RH. 2017). Palijativna skrb djece u Hrvatskoj provodi se tamo gdje to dijete ili njegova obitelj želi, bilo da je riječ o vlastitom domu ili bolničkoj ustanovi (Kužnik; Kukuruzović, 2020). U Planu razvoja palijativne skrbi na području Zagrebačke županije 2018.-2024. navodi se kako bi se kod izgradnje novog 
objekta Specijalne bolnice za kronične bolesti dječje bolesti Gornja Bistra, za smještaj djece iz cijele Republike Hrvatske trebalo osigurati trideset palijativnih kreveta za bolnički palijativni smještaj dječjih bolesnika (Zagrebačka županija, 2018). Dobar primjer kod palijativne skrbi za odrasle je trenutni pilot-projekt Ministarstva zdravstva koji se provodi u KB Dubrava pod nazivom „Bolnica prijatelj palijative“ gdje bi palijativni pacijenti trebali biti smješteni $u$ sobama koje nalikuju kućnim uvjetima pa tako sobe imaju zavjese, cvijeće, naslonjač za članove obitelji koji bi mogli u bilo koje doba dana i noći doći u posjet i prespavati u sobi pacijenta, ako to žele (Ministarstvo zdravlja, 2020).

Prilikom palijativne skrbi za dijete u obzir treba uzeti i dob djeteta te način komunikacije prilagoditi djetetovoj dobi, a prilikom planiranja skrbi u obzir treba uzeti kognitivne sposobnosti djeteta sukladno dobi. Djeci školske dobi važno je omogućiti nastavak školovanja u skladu s njihovim mogućnostima. Svaka Bolnica -prijatelj djeteta omogućava pedagoške sadržaje za djecu. Slično holističkom pristupu tijekom liječenja i kod učenja u bolnici učitelji djeci pristupaju individualno, prilagođavajući nastavu stanju svakog bolesnog djeteta. Danas postoje i vrtići u bolnici koji provode pedagoški kurikul predškolskog odgoja (Filipušić; Horvat; Lovrek Seničić, 2020).

\section{ULOGA VOLONTERA U} PALIJATIVNOJ SKRBI

Dio palijativnog multidisciplinarnog tima čine i volonteri. Zakon o volonterstvu kaže kako je volontiranje dobrovoljno ulaganje osobnog vremena, truda, znanja i vještina kojima se obavljaju usluge ili aktivnosti za dobrobit druge osobe ili za opću dobrobit, bez postojanja uvjeta isplate novčane nagrade ili potraživanja druge imovinske koristi (Zakon o volonterstvu, 2007). Jedan oblik palijativne skrbi podrazumijeva i skrb radi odmora njegovatelja. Roditeljima koji neprestano brinu za dijete potreban je odmor. Bilo da je riječ o odlasku u kupovinu ili odlasku na godišnji odmor bez djeteta. Oni roditelji koji su ostvarili status roditelja njegovatelja prema Zakonu o socijalnoj skrbi mogu koristiti odmor u trajanju do četiri tjedna tijekom godine (Središnji državni portal, 2014). Uloga volontera ovdje vrlo je važna te pomaže u pružanju i razvoju palijativne skrbi bilo da se dijete nalazi $u$ domu ili u nekoj ustanovi. Uvjet je da volonteri imaju dodatnu specifičnu edukaciju iz pedijatrijske skrbi, koja obuhvaća sve aspekte skrbi (Ministarstvo zdravstva, 2017). Ispitanici u istraživanju o 
volonterima u palijativnoj skrbi smatraju da je u Hrvatskoj teško unaprijediti volontiranje zbog nepovoljnog ekonomskog stanja $\mathrm{u}$ državi i nedovoljnog priznavanja/nagrada za volontiranje te smatraju da bi volontiranje trebalo biti više medijski popraćeno i da bi trebalo biti više edukacije u vrtićima, osnovnim i srednjim školama, fakultetima, a posebno u lokalnoj zajednici (manje sredine, ne samo veliki gradovi) (Žinić, 2019). Roditelji koji vode brigu o djetetu kojem je potrebna palijativna skrb su izloženi svakodnevnom stresu, umoru i naporu, gube samopouzdanje, često su socijalno izolirani i neshvaćeni. Majke najčešće preuzimaju brigu za dijete te su i više izložene navedenim rizicima (Martinac Dorčić, 2008).

\section{KATEGORIZACIJA DJECE U PALIJATIVNOJ SKRBI}

Djeca koja zahtijevaju palijativnu skrb kategorizirana su $\mathrm{u}$ četiri skupine. Palijativna skrb kod djece ne odnosi se samo na maligne bolesti ili ,terminalna stanja“ nego i bolesti poput cistične fibroze ili cerebralne paralize s kojima djeca uz dobru zdravstvenu skrb mogu produžiti život. Palijativnu skrb kod djece općenito karakterizira veći broj neonkoloških dijagnoza od onkoloških, za razliku od palijativne skrbi za odrasle (Preporuke Europskog udruženja za palijativnu skrb, 2009). Te četiri skupine razvile su $A C T$ Association for Children with Lifethreatening or Terminal Conditions and their Families i Royal College of Paediatrics and Child Health, a to su:

Skupina 1 - stanja koja ugrožavaju život, daju se liječiti, ali to liječenje ne mora uvijek biti uspješno, te pristup uslugama palijativne skrbi može biti nužan paralelno s liječenjem i/ili kad liječenje zakaže.

Skupina 2 - stanja kod kojih je preuranjena smrt neizbježna, ali mogu postojati duga razdoblja intenzivnog liječenja usmjerenog na produljenje života i omogućavanje normalnih životnih aktivnostima; primjer je cistična fibroza.

Skupina 3 - nelječiva progresivna stanja kod kojih je tretman isključivo palijativan i obično dugogodišnji, primjerice, Battenova bolest ili mišićna distrofija.

Skupina 4 - ireverzibilna, ali neprogresivna stanja koja iziskuju kompleksnu zdravstvenu skrb, praćena su komplikacijama, te je prerana smrt vjerojatna. Primjeri su teška cerebralna paraliza, te stanja nakon teških ozljeda mozga ili leđne moždine (Royal College of Paediatrics and Child Health, 1997). 
Istraživanje koje je provedeno u Hrvatskoj o smrtnosti djece 0-19 godina za razdoblje od 1995.-2012. godine izvještava da su na prvom mjestu uzroka smrtnosti nesreće/ozljede, a na drugom maligne bolesti, na trećem mjestu su prirođene malformacije, deformiteti i kromosomske abnormalnosti koje se u pojedinim godinama izmjenjuju s bolestima živčanog sustava (Mujkić i dr., 2014). Prema podatcima Hrvatskog zavoda za javno zdravstvo u 2015. godini u Zagrebačkoj županiji od malignih bolesti umrlo je dvoje djece (Hrvatski zdravstveno statistički ljetopis, 2015).

\section{KOMUNIKACIJA IZMEĐU TIMA, DJETETA, RODITELJA I OBITELJI}

Važna sastavnica palijativne skrbi za dijete je komunikacija između palijativnog tima koji brine za dijete i djeteta, roditelja te ostatka obitelji, pri čemu uvijek treba posebnu pozornost obratiti na braću i sestre djeteta koje zahtjeva palijativnu skrb jer se oni često osjećaju zapostavljenima. Pa tako uobičajena komunikacija zdravstvenih djelatnika koji brinu o djetetu kojem je potrebna palijativna skrb ima dodatnu komponentu, ne samo razgovor s djetetom već i s roditeljem. Prije svega, treba se pridržavati temeljnih odrednica dobre komunikacije. Preduvjet za uspješan razgovor je osiguravanje prikladne okoline pa je poželjno da u prostoriji budu samo one osobe kojih se razgovor $\mathrm{i}$ tiče, te treba osigurati da tijekom razgovora ne dolazi do prekida. Dobra komunikacija s pacijentom od posebnog značenja pred kraj života (Štifanić, 2009). Potrebno je strpljenje i razumijevanje jer će upravo to utjecati na razmišljanje i ponašanje roditelja i djeteta kojem je potreba palijativna skrb. $\mathrm{Na}$ umu treba imati nekoliko osnovnih principa $\mathrm{u}$ takvoj komunikaciji, a to su da bolesnici, u ovom slučaju roditelji i dijete, žele istinu o svojoj dijagnozi, bolesnicima se ne šteti razgovorom o temi završetka života, tjeskoba je normalna i kod bolesnika i kod liječnika tijekom takvih razgovora, bolesnici mogu imati druge ciljeve i prioritete od produženja života, te da shvaćanje bolesnikovih ciljeva i prioriteta omogućava pružanje kvalitetnije skrbi (Bernacki; Block, 2014). Mnoga ispitivanja zadovoljstva bolesnika sa zdravstvenim osobljem pokazuju da se većina njihovih zamjerki odnosi na nezadovoljavajuću komunikaciju sa zdravstvenim radnicima (Galović, 2016). To se uglavnom odnosi na prekratko vrijeme posvećeno razgovoru, premalo informacija ili zbog korištenja stručne terminologije roditelji, a pogotovo dijete, ne razumiju 
dobivene informacije. Bez obzira na težinu situacije dobro je koristiti osmijeh kada je to primjereno te paziti na neverbalnu komunikaciju. Predstaviti se roditeljima kako bi dijete steklo povjerenje u članove palijativnog tima prilikom prvog kontakta, a zatim se predstaviti djetetu. Uvijek je dobro spustiti se u razinu djetetovih očiju i oslovljavati ga imenom (Kozina; VičićHudorović, 2019). Roditelji se mogu osjećati krivima ali i ljutima, često tražeći krivca za bolest djeteta. Reakcija roditelja da dijete boluje ima četiri faze: stanje šoka, stanje odbijanja, osjećaj srdžbe, krivnje i gubitka te fazu prilagodbe (Mardešić, i dr. 2016). Palijativni tim treba pružiti roditeljima emocionalnu podršku. Često se $u$ tom slučaju u palijativni tim uključuju psiholog i/ili psihijatar.

Prije svega, djelatnici palijativnog tima procjenjuju znanje roditelja o bolesti i stanju djeteta, a roditeljima uvijek treba dopustiti postavljanje pitanja. Kada se roditeljima ili djetetu dopušta donošenje odluka, palijativni tim uvijek mora paziti da su odluke $\mathrm{u}$ najboljem interesu najprije za dijete, a zatim i za roditelje. Iskren i otvoren razgovor $\mathrm{s}$ konkretnim savjetima bez obećanja koje palijativni tim ili netko drugi ne može ostvariti preduvjet su za stjecanje povjerenja i uspješnu suradnju palijativnog tima i roditelja te djeteta. Tijekom cijelog procesa komunikacije važno je ne prijeći profesionalnu barijeru koliko god to $\mathrm{u}$ slučaju palijativne skrbi za dijete izgledalo teško.

\section{ZAKLJUČAK}

Palijativna skrb djetetu treba se pružati usporedno $\mathrm{s}$ aktivnim liječenjem te se nastaviti kao podrška roditeljima i obitelji tijekom procesa žalovanja nakon smrti djeteta. Palijativnu skrb obavlja multidisciplinarni tim raznih profesija, čiji pristup djetetu uvijek mora biti holistički. Uloga medicinske sestre u palijativnoj skrbi je višestruka. Omogućuje djetetu da se osjeća što ugodnije, bez bolova, te drugih simptoma, udovoljava njegovim duhovnim, socijalnim i psihološkim potrebama, te pruža pomoć i podršku i djetetovoj obitelji. Njena uloga je izazovna jer se nosi sa kliničkim i etičkim dvojbama te koordinira kompletnu skrb i timski rad u svim okruženjima. Pružajući palijativnu skrb, medicinska sestra razvija komunikacijske i intrapersonalne vještine, samosvijest te se kontinuirano usavršava. Palijativna skrb poboljšava kvalitetu života i djetetu kojem se skrb pruža i njegovoj obitelji. Palijativna skrb kod djece ne odnosi se samo na maligne bolesti nego $i$ bolesti poput cistične fibroze ili cerebralne 
Nastavnička revija 2 (2021) 1, 76-87

paralize s kojima djeca uz dobru zdravstvenu skrb mogu produžiti život. Roditeljima treba pružiti podršku preko mobilnog palijativnog tima, koji bi preuzeo značajnu, ali ne kompletnu palijativnu skrb djeteta u vlastitom domu. Svakom djetetu se treba pristupiti individualno i omogućiti mu koliko je moguće daljnje kognitivno učenje, kroz vrtić, školu u instituciji ili učitelje koji bi ga posjećivali kod kuće. Uključiti treba što više volontere sa dodatnom specifičnom edukacijom iz pedijatrijske skrbi, koji bi pomagali djetetu i roditeljima koji su izloženi svakodnevnom stresu, umoru i naporu, prvenstveno majkama koje najčešće preuzimaju brigu za dijete. Potrebno je strpljenje i razumijevanje jer će upravo to utjecati na razmišljanje i ponašanje roditelja i djeteta kojem je potreba palijativna skrb. Važna sastavnica palijativne skrbi mora biti komunikacija između palijativnog tima koji brine za dijete i djeteta, roditelja te ostatka obitelji kroz iskren $\mathrm{i}$ otvoren razgovor $\mathrm{s}$ konkretnim savjetima. Svi članovi tima trebaju zajednički planirati i provoditi potpunu skrb o djetetu i njegovoj obitelji, za vrijeme pružanja skrbi i tijekom procesa žalovanja, a njihove uloge i kompetencije trebaju se dijeliti i nadopunjavati.

\section{POPIS LITERATURE}

1. Bernacki , E.R.; Block, S.D. 2014. Communication about serious illness care goals: a review and synthesis of best practices.

https://pubmed.ncbi.nlm.nih.gov/253 30167/ (pristupljeno 28. srpnja 2020.).

2. Bedeković Sliško, M. 2018.

Percepcija boli u djece pri dijagnostičkim i terapijskim postupcima. Diplomski rad. Medicinski fakultet, Sveučilišni diplomski Studij sestrinstva. Zagreb.https://repozitorij.mef.unizg. hr/islandora/object/mef\%3A2046/dat astream/PDF/view (pristupljeno 9. srpnja 2020.).

3. Butković, D. 2014. Liječenje boli u djece. Medicus 23(2):127-137.

4. Centar za palijativnu medicinu, medicinsku etiku i komunikacijske vještine. $\quad$ https://mef.unizg.hr/onama/ustroj/centri/centar-zapalijativnu-medicinu-medicinskuetiku-i-komunikacijske-vjestine (pristupljeno 24. listopada 2020.).

5. Filipušić, I.; Horvat, I.; Lovrek Seničić, M. 2020. Zdravstvena njega bolesnog djeteta i adolescenta. Medicinska naklada. Zagreb. 
M. Lovrek Seničić, M. Kičić, A. Karabegović, Palijativna skrb u pedijatriji

6. Finella, C i dr. 2007. IMPaCCT: Standards for paediatric palliative care in Europe. European Journal of Palliative Care. 14. 2-7.

7. Galović, J. 2016. Odnos zdravstvenih djelatnika prema pacijentima. Završni rad. Zdravstveno veleučilište u Zgrebu. Zagreb.

https://urn.nsk.hr/urn:nbn:hr:139:467 989 (pristupljeno 28. srpnja 2020.).

8. Hrvatsko katoličko sveučilište, Izvedbeni planovi - sveučilišni studij sestrinstva.http://unicath.hr/izvedben i-planovi-20-21/odjel-za-sestrinstvo/ (pristupljeno 24. listopada 2020.).

9. Hrvatski zdravstveno statistički ljetopis za 2015. godinu. https://www.hzjz.hr/wpcontent/uploads/2017/02/Ljetopis_20 15_IX.pdf (pristupljeno 28. srpnja 2020.).

10. Kozina, M.; Vičić-Hudorović, V. 2019. Profesionalna komunikacija u sestrinstvu. Medicinska naklada. Zagreb.

11. Kužnik, K. Kukuruzović, M. 2020. Palijativna skrb djece u Hrvatskojgdje smo danas? Sestrinski glasnik. $2020 ; \quad 25: \quad 17-144$. https://hums.hr/publikacije/sestrinski -glasnik/\#220 (pristupljeno

24.

listopada 2020.).

12. Mardešić, D. i dr. 2016. Pedijatrija. Školska knjiga. Zagreb.

13. Martinac Dorčić, T. 2008. Razlike između majki i očeva djece s cerebralnom paralizom $u$ rizičnim $i$ zaštitnim faktorima te prilagodbi. Hrvatska revija za rehabilitacijska istraživanja.

https://hrcak.srce.hr/30720

(pristupljeno 27. srpnja 2020.).

14. Medicinski fakultet u Puli, Cjeloživotno obrazovanje, Palijativna skrb $\mathrm{s}$ kliničkom praksom.https://mfpu.unipu.hr/mfpu/ studijski_programi/cjelozivotno_obr azovanje/palijativna_skrb_s_klinicko m_praksom (pristupljeno 24. listopada 2020.).

15. Ministarstvo zdravstva, Republika Hrvatska. 2017. Nacionalni program razvoja palijativne skrbi u Republici Hrvatskoj 2017.-2020., Zagreb. https://zdravlje.gov.hr/nacionalniprogram-razvoja-palijativne-skrbi-urepublici-hrvatskoj-2017- 2020/3094 (pristupljeno 6. srpnja 2020.).

16. Ministarstvo zdravstva. 2020. Pilotski projekt „, Bolnica prijatelj palijative“ $\quad$ http://palijativna- 
$\underline{\text { skrb.hr/index.php/profesionalci- }}$

ustanove (pristupljeno 6. srpnja 2020.).

17. Mujkić, A. i dr. 2014.Smrtnost djece u Hrvatskoj u dobi 0-19 godina u razdoblju 1995.-2012. godine. XI. kongres Hrvatskog pedijatrijskog društva.

18. Odluka o zajedničkom obaveznom dijelu preddiplomskog sveučilišnog $\mathrm{i}$ preddiplomskog stručnog studijskog programa sestrinstva. Narodne novine, broj 150, 2011, čl.19.https://mzo.gov.hr/UserDocsIm ages//dokumenti/Obrazovanje/Visok oObrazovanje/RazvojVisokogObraz ovanja//Odluka\%20o\%20zajedni\%C 4\%8Dkom\%20obveznom\%20dijelu $\% 20$ preddiplomskog $\% 20$ sveu $\% \mathrm{C} 4 \%$ 8Dili\%C5\%A1nog\%20i\%20preddipl omskog\%20stru\%C4\%8Dnog\%20st udijskog\%20programa\%20sestrinstv a\%20u\%202015.\%20godini.pdf

(pristupljeno 24. listopada 2020.).

19. Preporuke Europskog udruženja za palijativnu skrb. 2009. Bijela knjiga o standardima i normativima za hospicijsku i palijativnu skrb u Europi: dio.http://www.kbcrijeka.hr/docs/Bij ela_knjiga_o_standardima_i_normati $\underline{\text { vima_za_hospicijsku_i_palijativnu_s }}$ krb_u_Europi.pdf (pristupljeno 6 . srpnja 2020.).

20. Royal College of Paediatrics and Child Health. Association for Children's Palliative Care. 1997. A guide to the development of children's palliative care services. Bristol.https://edisciplinas.usp.br/plu ginfile.php/4282446/mod_folder/con tent/0/ACT.\%20A\%20Guide\%20to \%20the\%20Development\%20\%20of \%20Childrens\%20Palliative\%20Car e\%20Services.pdf?forcedownload=1 (pristupljeno 24. listopada 2020.).

21. Središnji državni portal. 2014.https://gov.hr/mojauprava/obitelj-i-zivot/socijalnaskrb/prava-i-usluge-za-osobe-sinvaliditetom-iz-sustava-socijalne$\underline{\text { skrbi/pravo-na-status-roditelja- }}$ njegovatelja-ili-statusnjegovatelja/1804 (pristupljeno 6. srpnja 2020.).

22. Šilje, M. 2016. Uporaba metoda palijativne skrbi u djece. Sestrinski glasnik. July 21/2.

23. Štifanić, M. 2009. Kultura umiranje, smrt i žalovanje. Adamić. Rijeka.

24. Upravni odbor EAPC radne jedinice za palijativnu skrb djece i 
M. Lovrek Seničić, M. Kičić, A. Karabegović, Palijativna skrb u pedijatriji

adolescenata. IMPaCCT: standardi za pedijatrijsku palijativnu skrb u Europi. Prevela: prof. dr. sc. Karmen Lončarek.

25. Vuletić, S; Juranić, B; Mikšić, Š. Rakošec, Ž. 2014. Palijativna skrb i medicinsko-duhovne potrebe terminalnih bolesnika, Bogoslovska smotra,

84/4.,https://hrcak.srce.hr/133995

(pristupljeno 24. listopada 2020.).

26. World Health Organization.

Definition of Palliative care.

www.who.int/cancer/palliative/defini tion/en/_(pristupljeno 24. listopada 2020.).

27. Zagrebačka deklaracija o dječjoj palijativnoj skrbi. http://krijesnica.hr/2016/10/24/zagre backa-deklaracija-o-djecjojpalijativnoj-skrbi/?print=pdf (pristupljeno 24. listopada 2020.).
28. Zagrebačka županija. 2018. Plan razvoja palijativne skrbi na području Zagrebačke županije 2018. 2022.https://www.zagrebackazupanija.hr/ustrojstvo/upravni-odjelza-zdravstvo-socijalnu-skrb-ihrvatske-branitelje/palijativna-skrb/ (pristupljeno 6. srpnja 2020.).

29. Zakon o volonterstvu. 2007. Narodne Novine. https://narodnenovine.nn.hr/clanci/sluzbeni/2007_0 6_58_1863.html (pristupljeno 6 . srpnja 2020.).

30. Zdravstveno veleučilište u Zagrebu. https://www.zvu.hr/strucni-studijsestrinstva/ (pristupljeno 24. listopada 2020.).

31. Žinić, S. 2019. Volonteri u palijativnoj skrbi. Završni rad. Sveučilište Sjever. Varaždin. https://urn.nsk.hr/urn:nbn:hr:122:471 951 (pristupljeno 6. srpnja 2020.).

\section{SUMMARY}

\section{PALLIATIVE CARE IN PEDIATRICS}

Palliative care for children is defined and clear guidelines were given on its organization, but due to its specifics and complexity it is still underdeveloped. In the education of nurses, subjects dealing with the topics of palliative health care were included at the studies. Although each part of palliative care is important, the emphasis should be placed on recognition and pain management and good communication with parents. An important part of palliative care for children are volunteers. Education of volunteers in child palliative care requires an additional dimension, specific education in child palliative care. As children's palliative care begins at the moment of diagnosis and lasts through the grieving process after the child's death, the challenge is to maintain empathy.

Key words: children, palliative care, parents. 